\title{
Integrated management of Colletotrichum gloesporioides in yellow passion fruit (Passiflora edulis f. flavicarpa Degener)
}

\author{
Manejo integrado de Colletotrichum gloesporioides en el cultivo de \\ maracuyá amarillo (Passiflora edulis f. flavicarpa Degener)
}

Rodrigo Orlando Campo-Arana ${ }^{1}$; Naudith Urango-Esquivel${ }^{2}$; Dairo Pérez-Polo ${ }^{3}$

\begin{tabular}{ll}
\hline \multicolumn{2}{c}{ ARTICLE DATA } \\
\hline 1 Associate professor, Universidad de Córdoba, \\
Montería, Colombia, rocampoarana@correo. \\
unicordoba.edu.co \\
2 Agricultural engineer. Universidad de Córdoba, \\
Montería, Colombia, naudithurangoesquivel@ \\
correo.unicordoba.edu.co \\
3 Agricultural engineer. Universidad de Córdoba, \\
Montería, Colombia, dairoperez81@hotmail.com
\end{tabular}

Cite: Campo-Arana, R.; Urango-Esquivel, N.; Pérez-Polo, D. (2019). Integrated management of Colletotrichum gloesporioides in yellow passion fruit (Passiflora edulis f. flavicarpa Degener). Revista de Ciencias Agrícolas. 36(2): 87-94. doi: https://doi. org/10.22267/rcia.193602.120

Received: October 282018.

Accepted: June 142019.



\section{ABSTRACT}

Anthracnose (Colletotrichum gloeosporioides) is one of the most limiting diseases of yellow passion fruit, reducing crop production by more than $80 \%$. This research aimed to assess anthracnose management strategies on yellow passion fruit crop sanitation and yield. We assessed the effect of alternating fungicide applications (//) every 15 days with foliar nutrients on the severity of anthracnose and crop yield in a commercial crop in San Isidro district (Montería), located at coordinates 844'52.7” N, 7552'53.2”W and 75m.a.s.l. We conducted this research in two experiments; in the first, we assessed the response of the disease index (DI) after the application of the following treatments: T1=Manazeb (Mancozeb) // Potassium phosphite (Foscrop), T2=Mancozeb // Potassium (Terramin potassium), T3=Mancozeb // Calcium (Terramin calcium), T4=Trichoderma spp. (Fitotripen) // Copper oxychloride, T5=Azoxystrobin (Amistar) // Mancozeb, and T6=Control sprayed with water. In the second experiment, we selected the best treatments, as follows: $\mathrm{T} 1=$ Amistar // Mancozeb; T2 = Terramin potassium // Mancozeb, and T3 = Control. We evaluated DI, percent of affected fruits, number of fruits/ha, and yield (Kg/ ha). The results from the first experiment showed that T1 and T5 controlled anthracnose, reducing the levels of severity by $39.69 \%$ compared to the control (T6). In the second experiment, T1 decreased the levels of foliage severity by $29.04 \%$ and increased the number of fruits/ha and yield by $200 \%$ compared to the control. Overall, the fungicide application of Azoxistrobin alternating with Manazeb constitutes an effective alternative to control anthracnose in yellow passion fruit cultivation.

Keywords: Disease index; epidemiology; production losses; sanitation; strobilurin..

\section{RESUMEN}

La antracnosis (Colletotrichum gloesporioides) es una de las enfermedades más limitantes del cultivo de la maracuyá, reduciendo la producción en más del 80\%. Esta investigación tuvo como objetivo evaluar estrategias de manejo de antracnosis sobre la sanidad y rendimiento del cultivo de maracuyá. En un cultivo comercial, se evaluó el efecto de aspersiones con fungicidas alternados (//) cada 15 días con nutrientes foliares sobre la severidad de antracnosis y el rendimiento en el corregimiento de San Isidro (Montería), ubicado en las coordenadas: $8^{\circ} 44^{\prime} 52,7^{\prime \prime} \mathrm{N}$ y $75^{\circ} 52^{\prime} 53,2^{\prime \prime} 0$ a $75 \mathrm{msnm}$. En el primer ensayo, se evaluó la respuesta del índice de la enfermedad (IE) después de la aplicación de 


\begin{abstract}
los tratamientos: T1=Manazeb (Mancozeb) // Fosfito de potasio (Foscrop), T2=Mancozeb // Potasio (Terramin potasio), T3= Mancozeb // Calcio (Terramin calcio), T4=Trichoderma spp. (Fitotripen) // Oxicloruro de cobre, T5=Azoxistrobina (Amistar) // Mancozeb, T6=Testigo con agua. En el segundo ensayo, se escogieron los mejores tratamientos: T1=Amistar // Mancozeb; T2=Terramin potasio // Mancozeb y T3=Testigo. Se evaluaron el IE, frutos afectados (\%), número de frutos/ha y rendimiento (kg/ha). En el primer ensayo, T1 y T5 controlaron la antracnosis, disminuyendo un 39,69\% los niveles de severidad con respecto a la ausencia de control (T6). En segundo ensayo, T1 disminuyó los niveles de severidad del follaje en 29,04\% e incrementó en 200\% el número de frutos/ha y el rendimiento, con respecto al testigo. La aplicación alternada de los fungicidas Azoxistrobina y Manazeb constituye una alternativa efectiva de control de la antracnosis en el cultivo de maracuyá.
\end{abstract}

Palabras clave: Epidemiología; estrobilurina; índice de enfermedad; pérdidas producción; sanitación.

\section{INTRODUCTION}

In the department of Córdoba, yellow passion fruit is produced by small-scale growers, particularly, families that rely on this crop for sustainment. The most important region that produces yellow passion fruit is San Isidro district (municipality of Montería), which supplies the markets of Barranquilla, Cartagena, and Montería (Campo, 2008).

Anthracnose (Colletotrichum gloeosporiodes) is one of the most limiting diseases of yellow passion fruit (Passiflora edulis f. flavicarpa. Degener) crop in the department of Córdoba since it can reduce the life of the crop from 36 to 18 months and decrease production by over $80 \%$ (Campo-Arana et al., 2015). This disease has reduced crop area planted from 1024 ha in 2007 to 241 ha in 2014, as well as crop yield from 16.993 to $3.417 \mathrm{t}$ in $\mathrm{t}$ (Agronet, 2017). In the municipality of Montería, in 2007, there were 200 ha that provided $2400 \mathrm{t}$; however, this crop area decreased to 32 ha with yields of 480t in 2014 (Agronet, 2017). The fungi C. gloeosporioides not only affects yellow passion fruit but also mango, papaya, soursop, avocado, and tomato tree. Moreover, there are reports of other species, such as C. gossypii var cephalosporioides, affecting cotton (Zainuri et al., 2001; Barbosa et al., 2008). Disease symptoms begin with the appearance of circular lesions in the leaves, light color with a yellow border, followed by necrosis of the apical meristems and elongated lesions in the stems and petioles, causing defoliation and death of the plant. Anthracnose also affects the flowers, causing circular lesions in petals that finally result in petal loss (Sousa et al., 2014; Campo-Arana et al., 2015). In fruits, the symptoms manifest through deep circular lesions that form tumors and affect fruit quality (Rodríguez and Niño, 2009). Under favorable environmental conditions, fungal sporulation produces salmon-colored conidia in the center of the lesions and, ultimately, causes the fall of the fruits (SIPSA, 2014).

The epidemics of $C$. gloeosporiodes is favored by high temperatures $\left(28-32^{\circ} \mathrm{C}\right)$, relative humidity between $80 \%$ and $95 \%$, and annual precipitation above $1000 \mathrm{~mm}$, with frequent and intense rainfall, high cloudiness, and constant moisture that increase the duration of the dew point on the different plant organs. The disease worsens when the crop is cultivated at high densities and under high soil humidity (Páez, 1995).

Anthracnose management is deficient since some growers apply unsuitable fungicides for disease control, leading not only to environmental pollution but also an increase in production costs and lower crop profits (Campo, 2008). A similar situation occurs with other fruit-tree crops due to losses by anthracnose (SIPSA, 2014). 
The difficulties to anthracnose management include the presence of races in the genus Colletotrichum with varying degrees of virulence and resistance to fungicides, as well as inadequate disease management due to the lack of sanitation practices, crop fertilization, and genetic resistance (Degras et al., 1984; Agrios, 1997; Campo-Arana et al., 2015; Sousa et al., 2014). This pathogen causes high post-harvest losses; therefore, requiring the use of fungicide treatments. However, the use of fungicides does not lower disease incidence so alternatives for disease control are required (Aular et al., 2001).

Overall, anthracnose remains as an epidemic and fungicide-resistant disease that affects yellow passion fruit production. Therefore, the search for environmentally friendly alternatives for disease control is necessary. For instance, the use of heavy metal-based inductors of resistance has demonstrated significant results (Balardin et al., 2006). In view of this, this research aimed to assess anthracnose management strategies on yellow passion fruit sanitation and yield through the application of foliar fertilizers, fungicides, and antagonistic fungi to minimize fungicide use in this production system.

\section{MATERIALS AND METHODS}

We conducted two experiments during two consecutive years in a one-year-old commercial crop of yellow passion fruit located in San Isidro district, municipality of Montería (Colombia), at coordinates $8^{\circ} 44^{\prime} 52.7^{\prime \prime} \mathrm{N} 75^{\circ} 52^{\prime} 53.2^{\prime \prime} \mathrm{W}$ and $75 \mathrm{~m}$.a.s.l. We established a distance of $4 \mathrm{~m}$ between plants and $3 \mathrm{~m}$ between ridges. Prior to the first experiment, we performed phytosanitary pruning by removing branches and terminals affected by $C$. gloesporioides to reduce the presence of the fungus and disease. Then, we performed three applications of Carbenzim (Carbendazim) that allowed reaching plant sanitation within a month. We used a completely randomized block design with six treatments and three repetitions. Each experimental unit comprised eight plants. The treatments involved a bimonthly application of fungicides alternating with the application of a foliar fertilizer or biofungicide, as described in Table 1. Finally, we assessed disease severity according to the scale of Costa and Fraga-Júnior (1937), with modifications for yellow passion fruit and transformed using the disease index (DI) proposed by McKinney (1923) using the equation 1 :

$$
D I=\frac{\sum(\text { Degrees of the scale } x \text { Frequency })}{N^{\circ} \text { plants } x \text { Maximum degree }} \times 100
$$

Table 1. Biofungicide and fungicide treatments alternating with foliar fertilizers for anthracnose management in a commercial crop of yellow passion fruit in San Isidro, Colombia.

\begin{tabular}{cll}
\hline Treatment & $\begin{array}{c}\text { First application of the fungicide } \\
\text { or biofungicide }\end{array}$ & Second application of the foliar fertilizer \\
\hline 1 & Manazeb (Mancozeb, $5 \mathrm{~g} / \mathrm{L})$ & Potassium phosphite (Foscrop, $2 \mathrm{cc} / \mathrm{L}$ ) \\
2 & Manazeb (Mancozeb, $5 \mathrm{~g} / \mathrm{L}$ ) & Potassium (Terramin potassium, $1.5 \mathrm{cc} / \mathrm{L}$ ) \\
3 & Manazeb (Mancozeb, $5 \mathrm{~g} / \mathrm{L})$ & Calcium (Terramin calcium, $5 \mathrm{cc} / \mathrm{L}$ ) \\
4 & Trichoderma spp. (Fitotripen, $2 \mathrm{~g} / \mathrm{L})$ & Copper oxychloride $(4 \mathrm{~g} / \mathrm{L})$ \\
5 & Azoxistrobin (Amistar, $0.5 \mathrm{~g})$ & Manazeb (Mancozeb, $5 \mathrm{~g} / \mathrm{L}$ ) \\
6 & Water (control) & Water (control) \\
\hline
\end{tabular}


We conducted the second experiment between June and December, in the same commercial crop, during a subsequent crop production stage. In this experiment, we assessed the two best treatments obtained from the first experiment. Similar to experiment 1 , we performed phytosanitary pruning and sprayings with Carbendazim to eradicate the visible symptoms of the disease prior to establishing the experimental plots. We used a completely randomized block design with five repetitions and three treatments, namely T1=Azoxistrobin (Amistar, $0.5 \mathrm{cc} / \mathrm{L}$ ) alternating with sprayings of Manazeb (Mancozeb, 5cc/L) after 15 days; T2=Potassium phosphite (Foscrop, 2cc/L) alternating with sprayings of Manazeb (Mancozeb, 5cc/L) after 15 days; T3=Control with water sprayings. We applied the treatments for three months.

We performed periodical assessments for four months to determine the disease index based on the methodology described for the first experiment. After four months of application of the products, we determined the percent of affected fruits, the number of fruits/ha, and yield ( $\mathrm{kg} / \mathrm{ha})$. We calculated the percent of affect fruits by counting the number of affected fruits in each plot after harvesting. Additionally, we estimated fruit weight by randomly weighing 20 fruits per plot.
We analyzed the data from the two experiments through an Analysis of Variance $(p \leq 0.05)$ and a test for the significance of difference between means SDM $(p=0.05)$. The data were processed with SAS version 9.1 statistical software.

\section{RESULTS AND DISCUSSION}

First experiment. The analysis of variance showed significant differences $(p \leq 0.05)$ in antrachnose severity between treatments (Table 2). The application of treatments T1 (Mancozeb alternating with potassium phosphite) and T5 (Mancozeb alternating with Azoxistrobin) showed outstanding control on anthracnose by significantly reducing the levels of severity by $34.41 \%$ and $44.97 \%$, respectively, compared to the control (Table 2). Our results agree with reports by Kumar and Sugha (2003) on eggplant, demonstrating reduced Phomopsis fruit rot by $36.4 \%$ through the application of high doses of phosphorus. According to Castellanos et al. (2015), phosphorus serves as an inductor of resistance by strengthening the anatomical structures and inducing biochemical signals for plant defense against pathogens. Likewise, strobilurins (Azoxystrobin) have been efficient in the management of $C$. gloesporoides in papaya (Santamaría et al., 2011).

Table 2. Effect of biofungicides and fungicides alternating with foliar fertilizers on the severity index of anthracnose on yellow passion fruit crop, in San Isidro, Córdoba.

\begin{tabular}{ll}
\hline \multicolumn{1}{c}{ Treatment } & DI \\
\hline 1=Manazeb (5 g/L) // Potassium phosphite (2 cc/L) & $33.05 \mathrm{bc}$ \\
2=Manazeb (5 g/L) // Potassium (1.5 cc/L) & $53.51 \mathrm{ab}$ \\
3=Manazeb (5 g/L) // Calcium (5 cc/L) & $57.55 \mathrm{a}$ \\
4=Trichoderma spp. (2 g/L) // Copper oxychloride (4 g/ L) & $60.12 \mathrm{a}$ \\
5=Azoxistrobin (0.5 g/L) // Manazeb (5 g/L) & $27.73 \mathrm{c}$ \\
6=Water (control) & $50.39 \mathrm{ab}$ \\
Between treatments (P-value) & $0.0395^{*}$ \\
\hline
\end{tabular}

$\mathrm{DI}=$ disease index; *: Significant differences at the 0.05 level. Means with similar letters are not significantly different, according to SDM ( $p=0.05)$. 
Concerning Mancozeb, Ferreira et al. (2009) mention that this active ingredient is ineffective against $C$. gloesporoides under in vitro conditions; accordingly, these results contrast our findings.

Second experiment. The analysis of variance shows that disease severity and percent of affected fruits by anthracnose respond differently $(p \leq 0.05)$ according to the control method (Table 3). The application of Azoxistrobin alternating with Manazeb (T1) was the most effective treatment for the control of anthracnose since it reduced disease severity between 28.75 and $29.33 \%$, in July and October, respectively (Table 3). On the other hand, the response to the treatment with potassium phosphite alternating with Manzeb (T2) was similar to the control, suggesting that this nutrient does not induce resistance for leaf tissue protection (Table 3). Sousa et al. (2014) report lower values of anthracnose in yellow passion fruit (5.21 - 7.32\%) in greenhouse .

Our results agree with Pérez and Lannacone (2006), who report that fungicide application is not a completely efficient alternative since they did not find plants that were completely free from the pathogen attack. The effectiveness of Mancozeb against C. gloesporoides agrees with findings reported by Salazar (1998); likewise, our results for Azoxystrobin agree to those demonstrated by Santamaría et al. (2011), who obtained 87.5\% effectiveness against $C$. gloesporoides in papaya. The response to phosphorus differs from the reports by Mogollón and Castaño (2011), Hameed (2011) and Silva (2016), who mention that this product induces resistance and decreases the symptoms of Mycosphaerella spp. in Musa balbisiana AAB by 5.9\%; the severity of Fusarium verticilium in Solanum melongena by $7.5 \%$, and inhibited the presence of Colletotrichum musae in banana fruits by $28 \%$.

We observed a $68.75 \%$ reduction (compared to the control) in the percent of fruits affected by anthracnose in response to the application of Manazeb alternating with potassium phosphite (T2). The effect of the application of Azoxistrobin alternating with mancozeb (T1) was moderate or similar to the effect of phosphorus alternating with Manazeb as well as the control. This response suggests a low efficiency in fruit protection, yet a high efficacy in reducing the disease in the leaves (Table 3). These results differ from those reported by Fischer et al. (2012) and Chávez and Duarte (2018), who demonstrated that Azoxistrobin was the most effective active ingredient for reducing the severity of anthracnose in guava (Guignardia psidii) and strawberry [Fragaria $\times$ ananassa (Duchesne ex Weston) Duchesne ex Rozier] fruits.

Table 3. Effect of chemical treatments and inductors of resistance on the disease index in leaves and percent of fruits with anthracnose in a commercial crop of yellow passion fruit, in San Isidro, Córdoba.

\begin{tabular}{lccc}
\hline \multirow{2}{*}{ Treatment } & \multicolumn{2}{c}{ DI } & Fruits with \\
\cline { 2 - 3 } & July & October & anthracnose (\%) \\
\hline T1=Azoxistrobin // Manazeb & $32.57 \mathrm{~b}$ & $34.16 \mathrm{~b}$ & $13.00 \mathrm{ab}$ \\
T2=Potassium phosphite // Manazeb & $46.85 \mathrm{a}$ & $44.66 \mathrm{a}$ & $5.00 \mathrm{~b}$ \\
T3= Water (control) & $45.71 \mathrm{a}$ & $48.34 \mathrm{a}$ & $16.00 \mathrm{a}$ \\
Between treatments (P-value) & $0.0243^{*}$ & $0.0203^{*}$ & $0.0452^{*}$ \\
\hline
\end{tabular}

$\mathrm{DI}=$ disease index; ${ }^{*}$ : Significant differences at the 0.05 level. Means with similar letters are not significantly different, according to SDM ( $p=0.05)$. 
The response of yellow passion fruit to the application of phosphorus allows inferring the role of this heavy metal as an inductor of resistance. Accordingly, these findings agree with reports by Barbosa (2008), which demonstrated that the application of phosphite reduces the severity of anthracnose in yellow passion fruit during post-harvest. In contrast, our results differ from those in Salazar (1998), in which the preventive application of Manazeb alternating with curative fungicides results in lower incidence and severity of $C$. gloesporides in yellow passion fruit.

Regarding crop production, the analysis of variance showed that the number of fruits and yield were influenced $(p \leq 0.01)$ by the method of control (Table 4). The highest number of fruits/ha and yield were found through the application of Azoxistrubin alternating with Manazeb, resulting in a 200\% increase compared to the control (Table
4). These results suggest a direct relationship between yield and the leaf sanitation achieved by this control alternative (Table 3). The response of yield to fungicide application differs from the findings in Salazar (1998), which demonstrate the effectiveness of fungicides against $C$. gloesporides, but not on yield.

\section{CONCLUSIONS}

The application of Azoxistrobin alternating with Manazeb is an effective alternative for the control of anthracnose since treated plants develop healthier foliage. This response led to a $200 \%$ increase in yield and a greater harvest of fruits/ha compared to the control without treatment.

Conflicts of interest: The authors declare no conflicts of interest.

Table 4. Number of fruits/ha and yield ( $\mathrm{kg} / \mathrm{ha}$ ) of a commercial crop of yellow passion fruit in San Isidro, Colombia, in response to chemical treatments and inductors of resistance.

\begin{tabular}{lcc}
\hline \multicolumn{1}{c}{ Treatment } & $\begin{array}{c}\text { Number of } \\
\text { fruits/ha }\end{array}$ & $\begin{array}{c}\text { Yield } \\
\text { (kg/ha) }\end{array}$ \\
\hline Azoxistrobin +Manazeb & $2499.00 \mathrm{a}$ & $416.50 \mathrm{a}$ \\
Potassium phosphite+Manazeb & $1249.50 \mathrm{~b}$ & $208.25 \mathrm{~b}$ \\
Water (control) & $833.00 \mathrm{~b}$ & $138.83 \mathrm{~b}$ \\
Between treatments ( -value) & $0.0011^{* *}$ & $0.0011^{* *}$ \\
\hline
\end{tabular}

**: Significant differences at the 0.01 level. Averages with similar letters vertically do not differ significantly, according to the SDM $(p=0.05)$. 


\section{BIBLIOGRAPHIC REFERENCES}

Agrios, G.N. (1997). Enfermedades de las plantas ocasionadas por hongos. $4^{\text {th }}$ Ed. California: Academic Press. 635p.

Agronet - Red de información y comunicación del sector Agropecuario Colombiano. (2017). Estadísticas: Producción y agronegócios. Recovered from http:// www.agronet.gov.co/estadistica/Paginas/default. aspx

Aular, J.; Ruggiero, C.; Durigan, J. (2001). Efecto de la aplicación de Thiabendazole y del tratamiento térmico sobre la post cosecha de la parchita maracuyá. Bioagro. 13(2): 79-83.

Balardin, R.; Dallagnol, L.J.; Didone, H.T.; Navarini, L. (2006). Influência do fósforo e do potássio na severidade da ferrugem da soja Phakopsora pachyrhizi. Fitopato. Bras. 31(5): 462-467. doi: $\quad$ http://dx.doi.org/10.1590/S010041582006000500005

Barbosa, J. (2008). Controle da antracnose (Colletotrichum gloeosporioides) pós-colheita do maracujá-amarelo (Passiflora edulis f. flavicarpa) por aplicações de fosfitos, água quente e 1-metilciclopropeno. Recovered from https://core. ac.uk/download/pdf/33530185.pdf

Barbosa, M.A.; Laranjeira, D.; Coelho, R.S. (2008). Physiological cost of induced resistance in cotton plants at different nitrogen levels. Summa Phytopathol. 34(4): 338-342. doi: http://dx.doi. org/10.1590/S0100-54052008000400007

Campo-Arana, R.0.; Escobar-Lopez, F.M.; SeguraCepeda, L.E. (2015). Patogenicidad de cepas de Colletotrichum gloeosporioides aisladas en distintos órganos de la planta de maracuyá amarillo (Pasiflora edulis F. flavicara 0. Deg). Fit. Col. 39(2): 41-44.

Campo, R.0. (2008). Informe proyecto final: Mejoramiento de la productividad sostenible de maracuyá Pasiflora edulis Var, flavicarpa, en la comunidad de San Isidro (Córdoba-Colombia. Montería: Universidad de Córdoba. 73p.

Castellanos, L., De Mello, R.; Silva, C. (2015). El Silicio en la resistencia de los cultivos a las plagas agrícolas. Cul. Trop. 36(E): 16-24.

Chávez, M. A.; Duarte, L. C. S. (2018). Efecto de fungicidas sobre la antracnosis (Colletotrichum fragariae Brooks) en plantines de frutilla [Fragariax ananassa (Duchesne ex Weston) Duchesne ex Rozier]. Investigación Agraria. 20(1): 38-50. doi: http://dx.doi.org/10.18004/investig.agrar.2018. junio.38-50

Costa, A.S.; Fraga-Júnior, C.G. (1937). Superbrotamento ou ramulose do algodoeiro. Campinas SP: Instituto Agronomico. 23p

Degras, L.; Arnolin, L.; Suard, C.; Pointout, R. (1984). Selection of Dioscorea alata cultivars of low susceptibility to anthracnose Colletotrichum gloeosporioides. Recovered from http://www.istrc. org/images/Documents/Symposiums/Sixth/6th_ symposium_proceedings_0113_section_6_627.pdf

Ferreira,J.B.; DeAbreu,M.S.; Pereira,I.S.; Fernandes, K.D.; Pereira, R.B. (2009). Sensibilidade de Colletotrichum gloeosporioides (mancha manteigosa do cafeeiro) a diferentes concentrações de fungicidas. Ciência $e$ Agrotecnologia, Lavras. 33: 2052-2058.

Fischer, I. H.; Da Silva, B.L.; Soares, A.R.; De Arruda, M.C.; Parisi, M.C.M.; Amorim, L. (2012). Efeito de fungicidas e produtos alternativos no controle da antracnose e da pinta preta da goiaba. Semina: Ciências Agrárias. 33(1): 2753-2766. doi: 10.5433/1679-0359.2012v33Supl1p2753

Hameed, F. (2011). Biocontrol of damping off and induce resistance of eggplant cultivars by Trichoderma harzianum. K. J. Agr. Sci. 3(1): 355-360.

Kumar, S.; Sugha, S.K. (2003). Comparison of Gompertz and Logistic models for the analysis of progress of Phomopsis leaf blight of brinjal. Plant. Dis. Res. 18(2): 187-189.

McKinney, H.H. (1923). Influence of soil temperature and moisture on infection of wheat seedlings by Helminthosporium sativum. J. of Agr Res. 26(5): 195218.

Mogollón, A.; Castaño, J. (2011). Efecto de inductores de resistencia en plántulas de plátano dominico hartón (Musa balbisiana AAB) contra Mycosphaerella spp. Rev. A. Col. Cien. Ex. Fis. Nat. 35(137): 463-471.

Páez, A. (1995). Comportamiento de variedades de mango a la antracnosis. Fit. Col. 19(1): 25-30. 
Pérez, D.; Lannacone, J. (2006). Control químico de la antracnosis causado por Colletotrichum gloeosporioides en el cultivo del camu camu (Myrciaria dubia Myrtaceae) en Ucayali, Perú. Fitopatol. Bras. 31(5): 6003.

Rodríguez, M.; Niño, N. (2009). Archivos de diagnóstico en laboratorio 2000-2009. Bogotá: Universidad Nacional de Colombia - Universidad Jorge Tadeo Lozano.

Salazar, H. (1998). Evaluación de fungicidas contra antracnosis (Colletotrichum gloeosporioides) en maracuyá y diagnóstico de sus enfermedades fungosas en Olancho, Honduras. Honduras: Universidad Zamorano. 66p.

Santamaría, F.; Díaz, R.; Gutiérrez, 0.; Santamaría, J.; Larqué, A. (2011). Control de dos especies de Colletotrichum causantes de antracnosis en frutos de papaya maradol. Rev. Mex. C. Agr. 2(5): 631-643.

Silva, E.; Pinto, F.; Valentim, M. (2016). Alternativas a fungicidas sintéticos no controle da antracnose da banana. Summa Phytopathol. 42(4): 340-350. doi: http://dx.doi.org/10.1590/0100-5405/2000

SIPSA - Sistema de Información de Precios y Abastecimientos del Sector Agropecuario. (2014). Antracnosis, importancia y manejo integrado en el cultivo de tomate de árbol (Cyphomandra betaceae). Recovered from https://www.dane.gov.co/files/ investigaciones/agropecuario/sipsa/insumos_ factores_de_produccion_ene_2014.pdf

Sousa, M.A.; Pires, M.C.; Peixoto, J.R.; Faleiro, F.G.; Blum, L.E. (2014). Reação de progênies de maracujazeiro azedo à antracnose. Biosci. J. 30(2): 563-570.

Zainuri, J.D.; Wearing, A.H.; Coates, L.; Terry, L. (2001). Effects of phosphonate and salicylic acid treatments on anthracnose disease development and ripening of 'Kensigtown Pride' mango fruit. Aust. J. Exp. Agric. 41: 805-813. doi: https://doi.org/10.1071/ EA99104 